\title{
External and Internal Environmental Scanning Towards Strategic Design and Manufacturing a New Safety Car
}

\author{
AidanazimaAbashah $^{\text {a }}$, WuriHandayani ${ }^{\mathrm{b}}$, ShahrimanA.B ${ }^{\mathrm{c}}$, A. Harun ${ }^{\mathrm{d}}$, Z.M. Razlan ${ }^{\mathrm{e}}$, M.S.M. Hashim , W.K. \\ $\mathrm{Wan}^{\mathrm{g}}$
}

${ }^{a}$ School of Business Innovation \&Technopreneurship, University Malaysia Perlis,

${ }^{\mathrm{b}}$ FakultasEkonomikadanBisnis, UniversitasGadjahMada Indonesia,

c,d,e,f,g School of Mechatronic Engineering, University Malaysia Perlis,

a,b,c,d,e,f,g Motorsports Technology Research Unit (MoTech), University Malaysia Perlis

aaidanazima@unimap.edu.my, ${ }^{b}$ wurihandayani@ugm.ac.id, ${ }^{\mathrm{c}}$ shahriman@unimap.edu.my, ${ }^{\mathrm{d}}$ aziziharun@unimap.edu.my,

ezuradzman@unimap.edu.my, ${ }^{\mathrm{f}}$ sanihashim@unimap.edu.my, ${ }^{\mathrm{g}}$ khairunizam@unimap.edu.my

Article History: Received: 10 November 2020; Revised 12 January 2021 Accepted: 27 January 2021; Published online: 5 April 2021

\begin{abstract}
The automotive industry is among the prominent industry contributing to the Malaysian GDP rose by $3.6 \%$, with a value of RM 40 billion in 2016. The automotive industry is one of the fastest-growing economic sectors in all other sectors with the primary purpose of providing safe and accessible transportation for the world's increasing population. The vehicle owner and demand increase, but in the same way, road traffic accidents reported higher each year even though ASEAN NCAP has been introduced to improve the car safety level. Thus, this study aims to investigate further the technology shift and design features as external and internal environmental scanning towards car safety design and manufacturing from car manufacturer perspectives
\end{abstract}

Index Terms: External and Internal Environmental Scanning, Technology, Design, Car Safety, Automotive Industry.

\section{Introduction}

The government has recognized Malaysia's motor vehicle industry as an essential contributor to the economy with its expected contribution of $10 \%$ to our GDP in 2020.According to the Motor Trader and the Star Online, vehicle sales in ASEAN will reach 4.7 million units in 2018, compared to 2.4 million units in 2011. In turn, this brings ASEAN place the $6^{\text {th }}$ rank the most prominent automotive market by 2018 [15]. Thailand, Indonesia, and Malaysia are dominating the ASEAN auto market, and the number of the car in ASEAN road is estimated reach to 55 million units [4]. However, according to the WHO world's report, road accidents have brought public health and development problems, killed more than 1.2 million people a year, and injured or disabled between 20-50 million people. Moreover, the impact of such injuries, on average, costs about $1 \%$ to $2 \%$ of their national GDP [14].

Recent statistics from the Malaysian Ministry of Transport report that total road accidents increase gradually from 363,319 cases in 2007 to 521,466 cases in 2016. This suggests a further study by looking backward on the automotive industry as one element in the automotive ecosystem [11], particularly in the stage of designing and manufacturing a new car with the concern of continuous research and development (R\&D). R\&D and technology must come together, and it is a must to gain a competitive advantage and also to fulfill the ASEAN NCAP requirement [1].

Hence, the study to analyze how car manufacturers improve vehicle safety is crucial. Moreover, there is a dearth in the

literature exploring the issue of car safety from a manufacturer's perspective. Thus, this study explores car engineers' perceptions and attitudes towards car safety and how they transform their understanding of establishing policy and design and manufacture a new car. Moreover, this study also intends to investigate how a safety car is considered one of strategy to improve companies' competitive advantage. This is because enhancing vehicle safety will benefit the customer in the short term, and the long term will help reduce road accidents significantly.

Complementary to this research problem and the aim of this research, the proposed objectives for this study are as follow:

- $\quad$ To investigate the level of car safety and ASEAN NCAP understanding among car manufacturer

- To investigate how car manufacturer embedded/implement the technology shift into the designing and manufacturing stage of new car safety 
- To investigate how car manufacturer embedded/implement the design features into the designing and manufacturing stage of new car safety

\section{Literature Review}

\section{Car Safety}

Car safety has become one of the growing issues in the world. WHO proves it, and World Bank reported that more than $50 \%$ are killed during the traffic accident are youth from 15 to 44 years old which most of them are breadwinners of the family [14]. Hence, the proposed recommendations actions for each country's government to reduce the prevalence of road accidents.

The accident basically can be influenced by three main factors : (1) human factors, such as drunk driving, driving experience, or restraint use; (2) vehicle factors, such as mandated and non-mandated equipment or vehicle design; or (3) the driving environment such as traffic signal, weather condition, road condition [9]. The main challenge in promoting road safety recently is closely related to motor vehicles' remarkable growth across the world. Moreover, due to car production relocation, there is also the extraordinary growth of automotive production in countries where the road safety management system is not fully developed. Recently, six of the top ten car producers are now middle-income countries such as China, India, Brazil, Russia, Mexico, and Thailand [19]. As a result, the road death per 100,000 population in the middle-income countries is still high, about 20.1, compared to low-income countries and high-income countries, 18.3 and 8.7, respectively [19]. This is because the safety net of global standards is gradually undermined by car production's high growth, which cannot pass the United Nations minimum crash test. Moreover, major car manufacturers in middle-income countries are fiercely competing with other companies, and the demand for mobility often exceed consumer awareness of the risk of road injury. Hence, improving car safety need the actions taken by all parties, especially for vehicle manufacturers [19].

Vehicle safety has been enhanced for the last thirty-five years. A study conducted by [12] proposed the advanced technology implemented by automotive industries in Malaysia to reduce the car accident in Malaysia. However, how the automobile producers in Malaysia implement such a recommendation is still questionable. This suggests studying how the companies perceived safety cars and how they transform this perception and attitude in designing and manufacturing a new car.

\section{External Factor - Technology Shift}

The technology shift and car design features are essential factors in the automotive industry's internal and external environmental scanning stage. This is important when the technological shift may influence the advancement and refinement of the latest devices, systems, and associated software that automotive manufacturers can use to conduct their business [13]. As business players in the automotive industry, the automotive manufacturer must be alert to all opportunities to stay competitive in the local market and be competitive in the global economy market.

A variety of current new technology in the automotive industry such as Intelligent Transport Systems (ITS) for alcolock and seatbelt lock, GPS, braking and steering system are fuelling innovation impacting strategic planning decisions to better determine market trends to enhanced car safety strategy decisions by Malaysian OEM car manufacturers [3].

The technology shift becomes the essentials for OEM car manufacturers to create new competitive advantages and stay competitive in the current market. For example, a proudly Malaysian national brand, PROTON plant located in TanjungMalim, uses robotic technology and is fully automated to perform efficiently with a high volume of production [17]. Therefore, the implementation of lean manufacturing processes in the TanjungMalim plant was an excellent PROTON decision.

The rapid growth in the automotive industry has been the opportunity for Malaysian economy development when the government provides an educated and skilled labour force through education institutions and skill institutes by implementing Technical and Vocational Education and Training (TVET). This education training provides knowledge and skills for employment. This situation currently allures the leading international automotive players and other related stakeholders, such as vendors for automotive, to support the industry through investment in Malaysia further.

\section{Internal Factor - Design Features}

As a business entity, one of the main factors of success is the product itself. A product with the latest and exciting feature will help a business entity to boost its appeal to potential buyers. According to [7], there are few factors to influence product launch success: 4P's product, price, promotion, and place. 
Moreover, any product produced is compulsory to fulfil the market needs and buyer's taste [5] in terms of design features that meet their specifications needs, especially the design concept and features that manage to offer the safest car for customers [2], [6]. The safest car might help the automotive industry formulate a good product marketing strategy by highlighting the safety car awareness to targeted potential buyers in their promotion.

Design features such as autonomous system, Intelligent Transport System (ITS), color, passive safety design, materials and component used, and body design are the specification required by car manufacturers to ensure the product offered is safe for their customers. These are a few elements that need to be stressed by the automotive industry at the designing and manufacturing stage to reduce road accident rates due to several causes. Safety must become the priority for car manufacturer another cost, and car manufacturer need to make sure the materials and components used have a significantly less environmental impact if a road accident happens as well as the body car design must incorporate with the standard of safety, size, and weight, aerodynamics as ASEAN NCAP requires. Design features will give a good impression of automobile product features, but even though the customers always want the best features combination, they are only willing to pay for what is necessary to provide the best advantage for them [10].

\section{Research Framework}

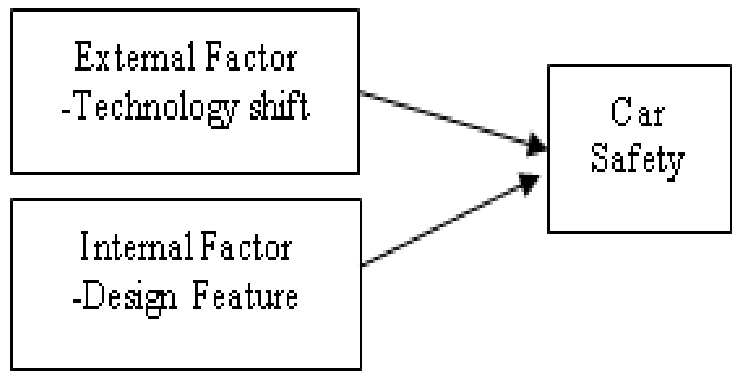

Figure 1. Proposed Research Framework

Therefore, the proposed hypothesis statement is:

H1: There is a significant relationship between technology shift towards designing and manufacturing car safety.

H2: There is a significant relationship between design features towards designing and manufacturing car safety.

\section{Implication Of The Study}

From the theoretical implication, this research is expected to understand car manufacturer understanding of car safety and how they implement the safety regulation provided by ASEAN NCAP within their career scope at the designing and manufacturing of a new car.

From practical implication, this research will bring evidence about car manufacturer understanding in Malaysia that needs further attention by MIROS and car manufacturers and vendors to improve car safety manufacturing. On the other hand, additional training, awareness, and safety regulation enforcement can be considered by MIROS as government agencies responsible for planning, managing, and evaluating road safety programs and conducting the related training.

\section{Conclusion}

The automotive industry is growing, vehicles owner and demand increase year by year, in the same way, accident rate increased even rules, and regulation was introduced, and enforcement bodies are taking many actions. Besides, most past research discovers the issues from passenger or customer perspectives, and lack of research has been done to learn from manufacturer perspectives. Therefore, the researcher considers that the analysis from manufacturer perspectives will help meet the proposed research objective for related stakeholder benefits, especially for consumers, automotive industry players, vendors, and MIROS.

\section{Acknowledgements}

This study couldn't be accomplished without support from the Malaysian Institute of Road Safety Research (MIROS) and Motorsports Technology Research Unit (MoTECH), University Malaysia Perlis. 


\section{References}

Abashah, A. Shahriman, A.B. Basri, H.H. RazindaTasnim, A.R. Harun, A. Razlan, Z.M.Hashim, M.S.M. Wan, W.K. (2019). Research \& Development (R\&D) in Strategic Production of a Safest Car. International Journal of Supply Chain Management, 8(4).

Clark, K. B., \& T. Fujimoto. Product Development Performance: Strategy, Organization, and Management in the World Auto Industry. Boston: Harvard Business School Press, 1991.

David F.R. \& David F.R. (2017). Strategic Management - A Competitive Advantage Approach, Concept and Cases. Sixteenth Edition. Pearson Education Limited.

Deutche Bank Research. (2011). ASEAN Auto Market : Growing in the Shadow of China and India.

Khalid, H. M. \&Helander, M. G. (2004). A Framework for Affective Customer Needs in Product Design, Theoretical Issues in Ergonomics. Volume: 14 issues: 3, page(s): 197-206.

Luchs, Brower, \&Chitturi, (2012). Product Choice and the Importance of Aesthetic Design Given the Emotionladen Trade-off between Sustainability and Functional Performance. Journal of Product Innovation Management 29(6).

McCarthy, E. J., \&Perreault, W. D. (1984). Basic Marketing: A Managerial Approach. Homewood, Ill: R.D. Irwin.

Glassbrenner, Donna. (2012). An Analysis of Recent Improvement to Vehicle Safety. Washington National.

Glassbrenner, Donna. (2012). An Analysis of Recent Improvement to Vehicle Safety. Washington National Highway Traffic Safety Administration.

Itamar Simonson, Carmon.,\& Suzanne O'Curry. Experimental Evidence on The Negative Effect of Product Features and Sales Promotions on Brand Choice. Published Online: February 1, 1994. Retrieved from https://doi.org/10.1287/mksc.13.1.23

Jawi, ZulhaidiMohd, \&Kassim, Khairil Anwar Abu. (2013). How does NCAP for ASEAN Help the Region's Road Safety Index. Paper presented at the Southeast Asia Safer Mobility Symposium 2013, Melaka, Malaysia.

Kassim, Khairil Anwar Abu, Jawi, ZulhaidiMohd, \& Isa, MohdHafzi Md. (2017). ASEAN's NCAP Contribution to Malaysia's Automative Ecosystem. Journal of the Society of Automotive Engineers Malaysia, 1(1), 20-32.

Lewis P. S., Goodman S. H., Michlitsch J. F., \&Fandt P. M. (2016). Management: Challenges for Tomorrows Leaders. Sixth Edition. SJ Learning.

Peden, Margie, Scurfield, Ricard, Sleet, David, Mohan, Dinesh, Hyder, Adnan A., Jarawan, Eva, \&Mathers, Colin. (2004). World Report on Road Traffic Injury Prevention. Geneva: The World Health Organization.

Prabnasak, Jaruwit, A P Taylor, Michael, \& Long Yue, Wen. (2011). Modelling Household Vehicle Ownership in Asian Medium-Sized Urban Area: A Case Study of KhonKaen City, Thailand. Journal of the Eastern Asia Society for Transportation Studies, 9, 196-210. doi: 10.11175/easts.9.196.

Press Release Gross Domestic Product Fourth Quarter 2017, Department of Statistics Malaysia, 14 February 2018.

Malaysian Investment Development Authority (MIDA), 2017. Business Opportunities-Malaysia Automotive Industry.

Motor Vehicle Sector Set to Contribute 10\% to GDP, The Star Online, 6 November 2017 retrieved at https://www.thestar.com.my/business/business-news/2017/11/06/motor-vehicle-sector-set-to-contribute10pc-to-gdp/

Ward, David. (2015). Democratising Car Safety : Road Map for Safety Cars 2020. United Kingdom: Global NCAP 